\title{
THE AGENDA-SETTING GOVERNMENT RESILIENCE FRAMEWORK: THE CASE OF ECONOMIC DIVERSIFICATION IN KAZAKHSTAN AND KYRGYZ REPUBLIC (2008-2017) ${ }^{1}$
}

\author{
O MODELO DE RESILIÊNCIA DE AGENDA-SETTING GOVERNAMENTAL: O CASO DA \\ DIVERSIFICAÇÃO ECONÔMICA NA REPÚBLICA DO CAZAQUISTÃO E QUIRGUISTÃO
} (2008-2017)

\section{EL MODELO DE RESILIENCIA DE LA AGENDA GUBERNAMENTAL: EL CASO DE LA DIVERSIFICACIÓN ECONÓMICA EN LA REPÚBLICA DE KAZAJSTÁN Y KIRGUISTÁN} (2008-2017)

Received: june/2019

Accepted: july/2019

Available online: august/2019

\begin{abstract}
Mergen Dyussenov, PhD in public policy (LKY School), National University of Singapore. The Head of the Anti-Corruption Research Center at the Academy of Public Administration under the President of Kazakhstan, Kazakhstan. E-mail: mergend7@gmail.com
\end{abstract}

\begin{abstract}
Resumo: Ao mesmo tempo em que adota uma abordagem centrada no ator para estudar as interações de definição de agenda, este artigo procura preencher uma lacuna na pesquisa de políticas públicas existente, assumindo explicitamente a capacidade e motivação do governo para resistir à pressão externa que é frequentemente exercida por outros atores- chave, através da introdução de um conceito de resiliência do governo aplicado na definição da agenda. Além disso, tenta quantificar a noção de resiliência do governo, abordando assim a questão da operacionalização de uma mudança na política pública. Refletindo os crescentes apelos entre os acadêmicos para que voltem seu olhar para as mudanças políticas no mundo em desenvolvimento, este artigo desenvolve um framework que pode ser útil não apenas na avaliação do grau de resiliência de um determinado ator, (por exemplo, o governo, aplicado à agenda), mas usado como uma ferramenta de diagnóstico para avaliar a capacidade do governo de perseguir sua agenda e implementar medidas políticas. Buscando explorar a potencial aplicabilidade do novo framework no contexto da diversificação econômica entre duas nações pós-soviéticas - Cazaquistão e Quirguistão - este estudo analisa o período de tempo de 2008-2017.
\end{abstract}

Palavras-chave : diversificação econômica, formação da agenda, resiliência, análise de conteúdo, Ásia Central, Cazaquistão, Quirguistão

1 This article was presented at GSPP Conference on Contemporary Issues in Public Administration in Post-Soviet Eurasia, October 5-6, 2018.

BRJPD | Vol. 1 | n. 1 | p.3-24, 2019 


\begin{abstract}
While similarly taking an actor-centric approach to studying agenda-setting interactions, this paper seeks to fill a gap in existing policy research by explicitly assuming the government's capacity and motivation to withstand the external pressure that is often exerted by other key actors, and thus by introducing a concept of government resilience as applied to agenda-setting. It furthermore attempts to quantify the notion of government resilience, thus addressing the issue of operationalizing a change in public policy. Reflective of growing calls among scholars to look into policy change in the developing world, this paper develops a framework that could be useful not only in assessing the degree of resilience of a certain actor, e.g. the government, as applied to agenda-setting but used as a diagnostic tool to assess the government's capacity to pursue its agenda and implement policy measures. Seeking to explore the potential applicability of the new framework in the context of economic diversification across two post-Soviet nations - Kazakhstan and Kyrgyzstan - this study looks into the time span of 2008-2017.
\end{abstract}

Keywords: economic diversification, agenda-setting, resilience, content analysis, Central Asia, Kazakhstan, Kyrgyzstan.

Resumen: Al tomar un enfoque centrado en el actor para estudiar las interacciones de la agenda, este artículo busca llenar un vacío en la capacidad y motivación del gobierno para resistir la presión externa que a menudo ejercen otros actores clave a través de la introducción de un concepto de resiliencia gubernamental en estableciendo la agenda. Además, los intentos de cuantificar la noción de que el gobierno de la resiliencia, solucionando así el problema de la implementación de un cambio en la política pública. Reflejando el creciente atractivo de los académicos para dirigir la mirada a los cambios políticos en el mundo en desarrollo, este artículo desarrolla un marco que puede ser útil no solo para evaluar la resistencia de un actor determinado (por ejemplo, el gobierno, aplicado a la agenda), pero utilizado como una herramienta de diagnóstico para evaluar la capacidad del gobierno para llevar a cabo su agenda e implementar medidas de política. Buscando explorar la aplicabilidad potencial del nuevo marco en el contexto de la diversificación económica entre dos naciones postsoviéticas, Kazajstán y Kirguistán, este estudio analiza el período de tiempo 2008-2017.

Palabras clave: diversificación económica, establecimiento de agenda, resiliencia, análisis de contenido, Asia Central, Kazajstán, Kirguistán

\title{
INTRODUCTION
}

The agenda-setting stage remains the most critical stage in the policy process, which pre-determines the remaining stages of the policy cycle (Howlett et al. 2009; Peters 2015). Since the original agenda-setting theory was developed by McCombs and Shaw (1972), which posits the strong role of mass media vis-à-vis other key actors in setting policy agenda e.g. the government and the public, this area of public policy research has evolved to incorporate not only a wider range of actors in agenda-setting interactions, e.g. academia, think tanks, advocacy groups etc. (e.g. see Dyussenov 2017 for a summary of major actors), but to analyze multiple directions and reciprocal causality patterns (e.g. Neuman et al. 2014).

All these evolutions notwithstanding, the agenda-setting theory has so far largely presupposed the government's rather passive stance (Boin et al. 2009, Kingdon 1984, McCombs and Shaw 1972). Especially relevant with regard to the government's interactions

BRJPD | Vol. 1 | n. 1 | p.3-24, 2019 
in the context of actor-centric agenda-setting processes is the work of Boin et al. 2009, who explicitly assume an ability of other actors, both inside and outside the government, to exploit emerging crisis events by aggressively pushing their own narratives and solutions and thus setting their agenda on the government. Their theory of crisis exploitation in agenda-setting posits the government's limited ability to withstand the pressure from external actors (ibid).

This paper seeks to fill this gap as applies to the evolving agenda-setting theory. First, it attempts to describe a new government resilience framework grounded on the explicit assumption of the actor's sufficient capacity and motivation to effectively withstand external pressure in the context of highly contested agenda-setting interactions among advocacy groups (Schattschneider 1960), or 'policy entrepreneurs' (Kingdon 1984), and among other actors either inside or outside the government (Boin et al. 2009). Second, reflective of the growing calls to analyze policy change in the developing world (e.g. Richardson 2009, Steinberg 2003), the new framework is applied to assessing the relative degree of government resilience across two Central Asian nations - Kazakhstan and Kyrgyzstan with regard to economic diversification.

\section{LITERATURE REVIEW}

The notion of resilience has increasingly become useful across a wide range of fields, predominantly within physical and ecological systems (Bodin and Wiman 2004, Holling 1973, Walker et al. 2004, Gunderson 2000, Tilman and Downing 1994 etc., as in Bhamra et al. 2011), climate change and disaster management (Surminski and Leck 2017, Leal Filho et al. 2016, Aoki 2016, Aoki 2015, McEvoy et al. 2013), psychology (e.g. Zautra et al. 2010 as in Capano and Woo 2017, Luthans et al. 2006 as in Vickers and Kouzmin 2001) especially children psychology (e.g. Benard 1993, Forman and Kalafat 1998, Stoiber and Good 1998 as in Vickers and Kouzmin 2001), criminology and mental health (as in Bourbeau 2015), NPM -driven organizational actors' resilience (e.g. McNulty and Ferlie 2004, Vickers and Kouzmin 2001, Hamel and Valikangas 2004), and engineering (Hollnagel et al. 2006 as in Vickers and Kouzmin 2001, Baker et al. 2004 as in Capano and Woo 2017).

\subsection{Review of resilience research in public policy}

Resilience has also recently sparked scholarly interest in the fields of public policy (Capano and Woo 2017, Boin et al. 2009), political science and international politics (Bourbeau 2015), and local governments (e.g. Lowndes and McCaughie 2013). The relative novelty of the resilience notion in public policy research suggests that scholars are yet to 
articulate with sufficient precision the evolving definition of resilience as applied to policy processes.

One useful way to analyze an array of definitions of resilience as applied to public policy processes is in terms of definitional rigidity. On one, somewhat rigid, side of the spectrum lies the definition of the resilience notion as suggested by Capano and Woo 2017, who assess the applicability of two related notions - resilience and robustness - across policy processes and policy design. In defining resilience, it is suggested that its key distinctive characteristic is "a heightened desire to maintain a stable equilibrium" (p. 407), as contrasted with the notion of robustness: "Unlike resilience, the stability that a robust system regains after recovering from shock... may not resemble its pre-shock state" (Capano and Woo 2017, p. 405). Next, in the middle of the spectrum is the definition of resilience developed by Nair and Howlett 2016, who analyze resilience as a crucial means of avoiding policy traps applied to climate change adaptation. Contrasting the two notions, the authors note that while robustness implies an ability of a policy to adapt to linear changes, resilience enables the policy not only to withstand linear but also non-linear context changes, and embraces "the elements of flexibility and adaptability, that is, the ability of the system to adapt and retain its key structure and functions under stress by being flexible" (Davoudi et al. 2012, as in Nair and Howlett 2016, p. 911). Last, but not least, on the other side is the definition offered by Bourbeau 2015. Inspired originally by criminologists and social workers, the author analyzes the notion of resilience through the lens of international politics, and defines resilience as "the process of patterned adjustments adopted by a society or an individual in the face of endogenous or exogenous shocks", and further referring to it as "an inherently dynamic and complex process" (Bourbeau 2015, p. 375). According to this specific definition, while change may originate from both external and internal sources, the outcome does not need to return to the pre-shock state of affairs.

To the contrary of the above-listed sources, McEvoy et al. 2013, while applying resilience to climate change adaptation in Australia through the lens of policy processes, fall short of providing a specific definition of resilience. First, the authors refer to the following three characteristics of the resilience concept as suggested by recent scholarly research: resilience is viewed as a response to disturbance; as a capacity of a system to self-organize; and as the learning and adaptation capacity (Adger et al. 2011, Turner II 2010, and Folke 2006, as in McEvoy et al. 2013). Second, the Australian federal government develops generic attributes of what should constitute resilience in Australian context, with community

BRJPD | Vol. 1 | n. 1 | p.3-24, 2019 
and organizational resilience being key elements in the new frame of resilience discourse as applied to climate change adaptation (Commonwealth of Australia 2011, as in McEvoy et al. 2013). This lack of a concise definition is not by any means negative, but is conducive to a plethora of solutions to address the wicked issue of climate change adaptation allowing policy makers to "address new challenges using system-based approaches" (Australia 21, 2009, as in McEvoy et al. 2013, p.289). Thus, this generic definition of resilience may travel across the degrees of definitional rigidity depending on a specific reference frame employed by different communities in resilience discourse (e.g. McManus et al. 2012, as in McEvoy et al. 2013).

The summary of the above definitions of resilience is outlined in Table 1.

Table 1: The spectrum of resilience definitional rigidity in the context of public policy

\begin{tabular}{|l|l|l|l|}
\hline \multirow{2}{*}{} & \multicolumn{2}{|c|}{ The degree of definitional rigidity } \\
\cline { 2 - 5 } & \multicolumn{1}{|c|}{ (Somewhat) rigid } & \multicolumn{1}{c|}{ Flexible Dynamic } \\
\hline Author(s) & Capano and Woo 2017 & Nair and Howlett 2016 & Bourbeau 2015 \\
\hline Brief context & $\begin{array}{l}\text { A critical assessment of } \\
\text { resilience and robustness in } \\
\text { the context of policy } \\
\text { processes and design. }\end{array}$ & $\begin{array}{l}\text { Applicability of resilience } \\
\text { versus robustness to climate } \\
\text { change adaptation. }\end{array}$ & $\begin{array}{l}\text { An application of the } \\
\text { resilience notion to the } \\
\text { politics and IR. }\end{array}$ \\
\hline
\end{tabular}

Source: The author's own analysis of literature

\subsection{Review of resilience research in agenda-setting}

While resilience discourse appears to be emerging in the context of public policy, there is a scarcity of resilience research specifically applied to agenda-setting processes. First, as mentioned earlier, McEvoy et al. 2013 look into resilience from the viewpoint of strengthening local communities in the face of climate change. Though the role of the federal government is recognized in terms of setting a partnership with local businesses and communities and developing a generic definition of resilience, McEvoy et al. 2013 view the notion of resilience as adaptation of communities to climate change, but not as government resilience against the external pressure of other actors in the context of agenda-setting. Similarly, while Capano and Woo 2017 attempt to answer the question: resilient against what? i.e. unexpected events, 'black swans' that tend to disturb the functions of society (Ho 2008, 2012a; Taleb 2010, 2012, as in Capano and Woo 2017), or crisis and 'focusing events' 
especially prominent in agenda-setting (e.g. Birkland 1998), the question: resilient against whom? i.e. other key actors that push their own agendas and solutions onto the government with regard to specific policy issues, remains largely unanswered.

One particularly interesting source that attempts to answer the 'resilient against whom?' question (as raised by Capano and Woo 2017) in the context of actor-centric agenda-setting processes comes from Boin et al. 2009, who analyze a series of cases related to framing contests as driven by 'focusing events' (Birkland 1998) that take place across EU nations. These crisis events are immediately exploited by other actors both inside and outside the government that seek to destabilize established policies and newly elected government figures by aggressively pushing their own frames and narratives and thus effectively setting their agendas on the government. This (agenda-setting) theory of crisis exploitation, defined as "the purposeful utilization of crisis-type rhetoric to significantly alter levels of political support for public office-holders and public policies" (Boin et al. 2009, p. 83), thus seeks to analyze both political and policy dimensions of impact. However, while the authors largely take an actor-centric approach to analyzing agenda-setting processes among the government and other actors e.g. media and opposition forces, they appear to largely imply the government's vulnerability with a limited capacity to effectively withstand pressure in the presence of aggressive players that only wait for a new crisis to exploit. Furthermore, similarly to the other research analyzed above, this study offers descriptive analysis of cases without any visible attempt to quantify or assess a degree of policy change. Finally, Boin et al. 2009 focus on EU democratic context, e.g. Spain, Belgium, Sweden etc., whereas scholars increasingly call for analyzing policy change in the developing world (e.g. Richardson 2009, Steinberg 2003). Thus there is a need for an alternative framework centered on government resilience in the context of agenda-setting in developing nations.

\subsection{The evolutionary theory of agenda-setting}

The original agenda-setting theory was developed by McCombs and Shaw (1972) that posits the strong role of mass media in setting political agenda. The essence of media's ability to shape the agenda can be expressed by borrowing Bernard Cohen's (1963) quote: "the press may not be successful much of the time in telling people what to think, but it is stunningly successful in telling its readers what to think about" (as cited in Dearing and Rogers 1996, p. 2). However, while early theories primarily looked into a simplified one-way

BRJPD | Vol. 1 | n. 1 | p.3-24, 2019 
direction of agenda-setting influence dominated by media, modern scholarship recognizes the importance of other actors e.g. the public, think tanks, academia etc. (see Dyussenov 2017 for an overview of actor-centered theories and frameworks in agenda-setting) and context and issue specificity, as well as the need to analyze multiple directions and reciprocal causality patterns (e.g. Neuman et al. 2014).

Agenda-setting is generally defined as the process in which policy issues capture the attention of government leaders. It is the first and most critical stage in the policy process that deals with the way policy issues emerge competing for government's attention. This stage largely pre-determines all the subsequent stages of the policy cycle and their outcomes (Howlett et al. 2009; Peters 2015). An agenda can be defined as the set of issues that government bodies will take action on (Cobb and Elder, 1972). Agenda-setting can be viewed as the "list of subjects" that government officials pay attention to, while their attention is greater to some issues than to the others (Kingdon 1984, pp. 3-4). Further, as Kingdon's multiple streams framework suggests, three independent streams - problem, policy and political - jointly interact to produce 'windows of opportunity' which are then seized by policy entrepreneurs to push their agendas on the government. This implicitly points to the potential presence of conflict among key stakeholders. Schattschneider (1960), on the other hand, more explicitly states that the involvement of political contestations and conflict is an integral part of agenda-setting processes. He articulates the notion of conflicts, or the scope of conflict, among various stakeholders and groups, in shaping and defining policy issues that should be included into the government agenda (ibid). Thus the government should intensify its resilience against the pressure from other actors, e.g. political opposition, media, academia and think tanks etc., if incumbent figures intend to pursue their own (government) agenda and lead key policy and political developments over a term. Surprisingly, agendasetting discourse so far has neglected to analyze and assess a degree of government resilience as applied to the context of actor-centric agenda-setting interactions. Combined with earlier observations from the literature review (section 2.2), this raises the need to develop a government resilience framework in the context of agenda-setting in developing nations.

\subsection{The government resilience framework in agenda-setting}

As noted above, the new framework is purported to fill a gap in existing research, i.e. by analyzing and assessing a degree of actor resilience in the context of agenda-setting 
interactions with other key actors, with an explicit assumption of the actor's capacity and motivation to withstand the pressure exerted by other actors in a setting characterized with contestation both among advocacy groups (Schattschneider 1960), or 'policy entrepreneurs' (Kingdon 1984), and among other actors either inside or outside the government (Boin et al. 2009).

The framework is both conceptual and theoretical. The new concept as applied to actor-centric agenda-setting is government resilience. Its definitional rigidity depends on the issue and context specificity and thus may take one of the three forms as in Table 1. It should be noted there is no clear dividing line between the three forms, and these can change over time depending on political context. It can be hypothesized that socially sensitive issues, e.g. violent crime and disaster response, may be characterized with dynamic resilience, while more technical issues, e.g. economic diversification, should exhibit rigid resilience traits. Furthermore, since the framework can assess a relative degree of government resilience, it should be applied to comparative cases of two and more nations and/or settings. It is also a theoretical framework as it stems from a number of agenda-setting theories, as described in detail above (Section III).

\section{METHODOLOGY}

The proposed methodology for the government resilience framework comprises two parts. The first part is to employ online government databases, e.g. Adilet.zan.kz legal database in Kazakhstan (The Ministry of Justice of the Republic of Kazakhstan 2018). For the case of Kyrgyzstan, two search systems are used - the Centralized Database (The Ministry of Justice of Kyrgyz Republic 2018), which generates results through 2014 (see details in Section V), and Google search filtered for site:www.gov.kg and then selecting documented mentions in the 2008-2017 span². The numbers of documents collected will be plotted on a graph over a time span to produce quantitative analysis observations for the two governments, with a specific focus on the most visible spike in attention. This is necessary in order to clearly observe which type of definitional rigidity applies most, and to test the applicability of the government resilience framework. The numbers of documents

\footnotetext{
${ }^{2}$ Understanding that the use of two (similar) databases may not produce consistent results, the author believes this is the best approach feasible in this situation.
}

BRJPD | Vol. 1 | n. 1 | p.3-24, 2019 
generated by the databases serve as a proxy for government attention to the issue. The government resilience framework is employed to analyze economic diversification policy across the two nations over the time span of 2008-2017. The rationale for focusing on this issue is driven by its recently growing importance both on political (Strategy2050.kz, 2014, as in Dyussenov 2017) and policy agendas (Toxanova 2008, as in Dyussenov 2017) in Kazakhstan. The rationale for choosing the 2008-2017 time frame is driven by two opposing factors. First, prominent scholars suggest that attempts to observe policy change would require at least a decade or more (e.g. Sabatier 1988, Heclo 1974). Specifically, when describing his advocacy coalition framework of policy change, Sabatier (1988) states that "....understanding the process of policy change - and the role of policy-oriented learning therein - requires a time perspective of a decade or more" (p. 131). The second factor is driven by lower internet penetration rates, e.g. in Kazakhstan, in the earlier part of the time span (which is the reason Dyussenov 2017 includes the 2011-2016 time frame for his analyses). Thus, the 10-year span is selected for this study.

The other part of the methodology is content analysis. Following the quantitative analysis by using the government databases described above, the content analysis method should be used to specifically analyze the documents collected during the year(s) of the most visible spike in attention to see 1) what (crises, or 'focusing' events, as in Birkland 1998) might be the cause of the intense government attention to the issue, i.e. answering the 'resilient against what?' question, and 2) identifying the actor(s) most prominently referred to in those documents that would indicate an answer to the 'resilient against whom?' question (provided that the government attention trends indeed return to some form of stability as suggested by the spectrum in Table 1).

To summarize, this study attempts to answer the following research questions:

- $R Q$ 1: Do the attention trends across both Central Asian nations point to the overall applicability of the government resilience framework in agenda-setting?

- RQ 2: provided that the framework applies, what are the critical, or focusing, events to which the governments exhibit resilience over the time span?

- RQ 3: provided that the framework applies, who are the key actors to which the governments most (or more) frequently refer to, based on the content of documents? Finally, as mentioned earlier, the major hypothesis as applied to the issue of economic diversification is that (somewhat) rigid or flexible resilience traits are expected to be observed across the two country cases, due to the technical nature of the issue. 


\section{ANALYSIS}

The analysis consists of two parts, quantitative and qualitative (content) analyses. First, quantitative analysis is conducted to 1 ) identify which degree of definitional rigidity applies to each of the two country cases over the time span, and 2) observe government attention trends in order to identify visible spikes, which should then become the focus of content analyses.

\subsection{Quantitative analysis}

\subsubsection{Kazakhstan}

The search for documents related to economic diversification in Kazakhstan over the 2008-2017 period returns the total of 324 documents, by using the following filters: decrees and strategies as forms of acts, current (as opposed to expired) status, and the government of Kazakhstan (Prime-Minister) and the President as bodies that adopted the bills (as opposed to other agencies, e.g. the National Bank, Parliament etc. since this study focuses specifically on government activities). The number of documents per year are as follows: 24 in 2008, 22 in 2009, 37 in 2010, 39 in 2011, 29 in 2012, followed by a 2-year spike of 42 in 2013 and 56 in 2014, followed by a new period of stable trends - 25 in 2015, 23 in 2016, and 27 in 2017 (Figure 1).

Figure 1: Kazakh government attention trends to diversification, 2010-2017

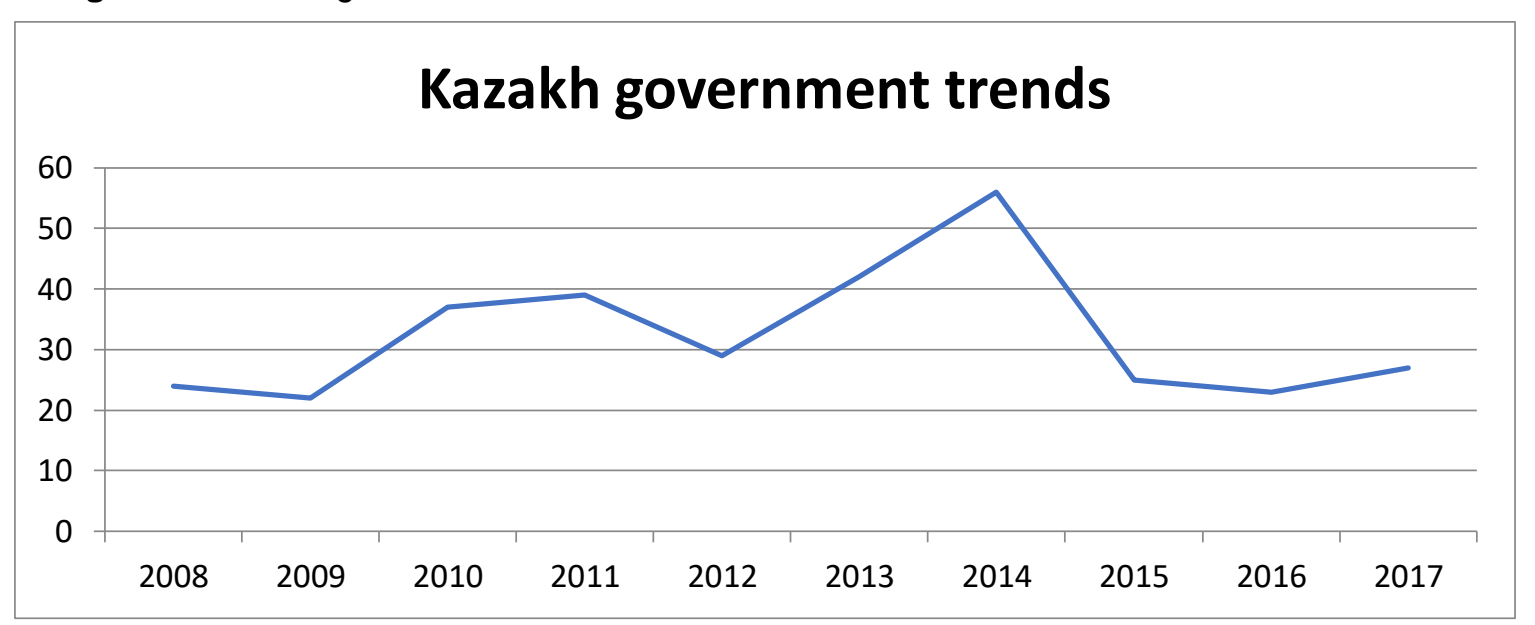

Source: The author's own analysis based on data from adilet.zan.kz database

Figure 1 demonstrates a number of interesting observations. First, it suggests that Kazakh government attention trends generally conform to the combination of "somewhat rigid" and "flexible" degrees of definitional rigidity of resilience (as in Table 1), namely that while attention trends largely fall in the range of 20-30 mentions per year in 2008-2009 and 
30-40 mentions per year in 2010-2012, then following the spike of 2013-2014, the post-spike period of 2015-2017 enters a new period of stable equilibrium again in the range of 20-30 mentions per year as in 2008-2009. Thus, the Kazakhstan government case supports the overall tentative validity of the new framework as applied to agenda-setting processes. Second, the trends reveal a clear spike in attention, i.e. 2013-2014. This 2-year span of heightened intensity should be the focus of content analysis (below).

\subsubsection{Kyrgyz Republic}

Next, the combined document search (based on two search systems) related to the Kyrgyz government case over the period produce the total of 96 documents, including 72 by the Centralized Database (filtered for current status documents) and 14 (screened for relevance) documents generated by Google search. The numbers of documents per year are as follow: 9 in 2008, 15 in 2009, 3 in 2010, 7 in 2011, followed by a three-year spike of 16 in 2012, 18 in 2013, and 15 in 2014, then followed by a sudden period of low stability, with 1 mention in 2015-2017 each (Figure 2). It should be noted that the overall number of documents in the Kyrgyzstan case is significantly lower than in the case of Kazakhstan. This is because Kazakhstan is a petroleum resource rich nation, which spurs intense debates among the local expert communities with regard to specific political and policy measures that should be adopted to push the agenda on economic diversification away from oil and gas dependency.

Figure 2: Kyrgyz government attention trends to diversification, 2010-2017

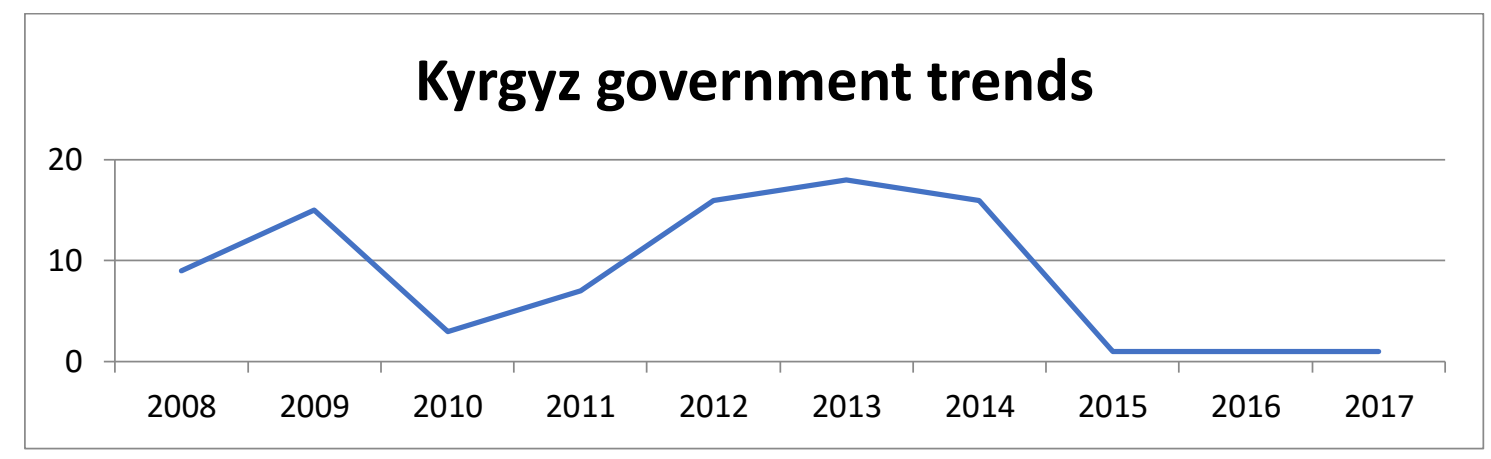

Source: The author's own analysis based on data from Centralized Database and Google

Figure 2 points to the following observations. First, Kyrgyz government attention trends are less clear vis-à-vis the Kazakh case and only vaguely seem to fall into the "flexible" degree of definitional rigidity. Specifically, the trends start off with what appears to be an earlier spike, not a period of stable trends, followed by a quick downward trend in 
2010 (3 documents) and then the period of somewhat a prolonged spike in government activity from 2011 to 2015 , especially in 2012-2014 which then should become the focus of content analysis that follows. The post-spike plain stable period appears somewhat counterintuitive especially following a 'drama' of prolonged heightened attention intensity. This could be explained by two possible factors. First, as in the Kazakh case, only current status legal bills and documents are selected, as opposed to the expired (i.e. no longer in force) and draft bills (i.e. yet to be enacted). Thus the Kazakh government might possess stronger capacity vis-à-vis its Kyrgyz counterpart to push legal bills quicker. The second possible explanation is the (still) ongoing process of digitization of government documents which make take longer in Kyrgyz Republic due to limited budget and/or other resources. In overall, it should be noted that the prolonged instability in trends may indicate that the Kyrgyz government is less resilient vis-à-vis its Kazakh counterpart. Again, the content analysis section below should either support or disprove these tentative observations and ensure better triangulation of research methods. Thus, although this case fails to clearly demonstrate a specific degree of definitional rigidity of the resilience concept, the framework remains useful as a diagnostic tool. The comparative case method embedded into the (government resilience) framework is also quite useful as it allows better observing relative variations among the cases.

\subsection{Qualitative analysis}

\subsubsection{Kazakhstan}

As suggested in Figure 1, the Kazakh case exhibits a spike in government attention to the economic diversification policy issue concentrated around 2013-2014. Thus content analysis should be carried out with regard to these documents specifically to identify 1) the key actors that the government more frequently refers to in its discourse on diversification policy (it should be noted that the more the documents emphasize the role of other actors at the expense of government's own expertise, the less resilient the government is viewed); and 2) what critical or 'focusing' events (as in Birkland 1998) spur intense debates within government discourse.

The total number of generated documents in 2013-2014 is 98 (42 and 56, accordingly). These documents are then screened to filter out those files not directly relevant to the essence of economic diversification policy, e.g. related to diversification of risks for pension funds etc., and to further include only those with meaningful substance, i.e. 
containing at least two references to economic diversification in a single document. Thus, in total 34 documents (15 for 2013 and 19 for 2014) are selected for content analysis.

First, with regards to the key actors identified, i.e. answering the 'resilient against whom? question (Capano and Woo 2017) in the context of Kazakhstan, these are outlined in Table 2.

Table 2: Key actors as suggested by content analysis, the case of Kazakhstan

\begin{tabular}{|c|l|c|}
\hline$\#$ & \multicolumn{1}{|c|}{ Key actors } & $\begin{array}{c}\text { The number of content } \\
\text { references }\end{array}$ \\
\hline 1 & The government & 38 \\
\hline 2 & Industries & 19 \\
\hline 3 & $\begin{array}{l}\text { The private sector, e.g. } \\
\text { SME }\end{array}$ & 17 \\
\hline 4 & Investors \\
\hline 5 & Academia and research & 8 \\
\hline 6 & Quasi-state enterprises & 7 \\
\hline 7 & $\begin{array}{l}\text { International } \\
\text { organizations }\end{array}$ & 2 \\
\hline 8 & The public & 6 \\
\hline
\end{tabular}

Source: The author's own analysis

Thus, the Kazakh government appears to predominantly refer to its own agencies (38 references, $35.5 \%$ of the total number of references) in its discourse on economic diversification policy, this is followed by the role of industries (19 references, or $17.8 \%$ ), the private sector, e.g. small and medium-sized business enterprises (17 references, or 15.8\%), investors (10 references, or $9.3 \%$ ), academia (8 references, or $7.4 \%$ ), quasi-state enterprises (7 references, or $6.5 \%$ ), international organizations (6 references, or $5.6 \%$ ), while the role of the public is less pronounced (2 references, $2 \%$ ). The observation that the government mainly refers to its own institutions as part of its discourse on economic diversification points to the possibility of government resilience as measured in terms of references to other key actors, including industries and the private sector. This is further 
triangulated by earlier observations from quantitative trends (Section 5.1.1) that found the Kazakh case to fall into the "somewhat rigid" category of resilience (as in Table 1).

Second, regarding the critical events, i.e. answering the 'resilient against what? question (Capano and Woo 2017), these can be categorized into the following groups as suggested by content analysis (Table 3 below): group 1 can be broadly titled as infrastructure-related critical events, mainly including new logistics terminals built at the Aktau sea port in West Kazakhstan and Khorgos terminals at Chinese the border, and the intercontinental road from Western Europe to Western China; group 2 incorporates global factors, e.g. the financial crisis; and group 3 includes a number of regional factors, e.g. the Customs Union and Single Economic Space.

Table 3: Critical events as suggested by content analysis, the case of Kazakhstan

\begin{tabular}{|c|c|c|}
\hline Groups & Critical events & The number of content references \\
\hline \multirow{4}{*}{$\begin{array}{l}\text { Infrastructure projects } \\
\text { (total }-6 \text { references) }\end{array}$} & $\begin{array}{l}\text { New logistical terminals, e.g. } \\
\text { Aktau sea port, Khorgos etc. }\end{array}$ & 2 \\
\hline & Oil pipeline expansion & 1 \\
\hline & $\begin{array}{l}\text { The Western Europe - Western } \\
\text { China corridor }\end{array}$ & \\
\hline & Refinery upgrade & 1 \\
\hline \multirow{4}{*}{$\begin{array}{l}\text { Global factors } \\
\text { (total }-5 \text { references) }\end{array}$} & Global competition & 1 \\
\hline & The financial crisis & 2 \\
\hline & Commodity prices & 1 \\
\hline & Sanctions against Iran & 1 \\
\hline \multirow{3}{*}{$\begin{array}{l}\text { Regional factors } \\
\text { (total - } 4 \text { references) }\end{array}$} & $\begin{array}{l}\text { Integration processes in the } \\
\text { macro-region }\end{array}$ & 1 \\
\hline & The Customs Union & 2 \\
\hline & Common Economic Space & 1 \\
\hline
\end{tabular}

Source: The author's own analysis

\subsubsection{Kyrgyz Republic}

BRJPD | Vol. 1 | n. 1 | p.3-24, 2019 
As Figure 2 suggests with regard to the case of Kyrgyz Republic, the major spike in government attention is spread over the 3-year time span from 2012 to 2014. The other sporadic spike around the year 2009 (with 15 references) turns out to be due to noise: as the two criteria of relevance and substance (as described in Section 5.2.1) are applied, this leads to the selection of only two documents for content analysis.

The total number of generated documents over the three-year time span is 41 , including 14 in 2012, 18 in 2013, and 9 in 2014. Further filtered based on relevance and substance criteria, the final number of documents selected for content analysis is 12 , including 6 in 2012 and 2013 each, followed by 4 documents in 2014.

First, in attempt to answer the 'resilient against whom?' question, the following key actors are identified in the process of content analysis of government discourse on economic diversification (as in Table 4 below): the government (11 references), then the private sector (7), closely followed by industries (6) and international organizations (6), and the public (5), while the role of investors appears less emphasized (2).

It is striking to observe a number of differences in the relative degree of government resilience across the two nations. First, the degree of Kazakh government resilience in relation to the next key actor, i.e. industries (38 to 19) is well higher than the degree of its Kyrgyz counterpart's resilience in relation to the next key actor, i.e. the private sector (11 to 7). Second, the Kazakh case presents a larger number of actors, i.e. 8 versus 6 in the Kyrgyz case, divided into three distinct groups in terms of the number of references: the top group - the government (the predominant actor), industries and the private sector; the intermediary group, i.e. with a moderate number of references - investors, academia, quasi-state agencies, and international organizations; and a single actor with a negligible number of references, i.e. the public (with 2 references only). Third, similar to the case of Kazakhstan, the Kyrgyz case presents the government in the top (but not quite predominant as in the Kazakh case), followed by the private sector and industries, with the difference among the latter two being negligible, i.e. 7 versus 6 references. However, while the public appears rather dormant in the Kazakh case, it seems more pronounced in the case of Kyrgyzstan, though not in the top of actors. This may point to the Kyrgyz government's greater responsiveness to public needs as compared to the case of Kazakhstan. Conversely, Kazakh government's resilience seems greater vis-à-vis the Kyrgyz case. This is an important observation, as it suggests that the notion of resilience can be linked to both positive and negative connotations depending on the context. Last, it is interesting to 
compare the role of investors perceived in government discourse. While investors immediately follow the top actors in Kazakh context, the Kyrgyz case attributes them a negligible role. Instead, the Kyrgyz government relies more on assistance from international organizations (e.g. Office of the Government of the Kyrgyz Republic, 2014; The National Council for Sustainable Development of the Kyrgyz Republic, 2013). On the contrary, the Kazakh case attributes relatively a lower role to international organizations vis-à-vis other key actors. Interestingly, this observation is further supported by public perceptions which view international organizations with negative sentiments (Dyussenov 2017).

Table 4: Key actors as suggested by content analysis, the case of Kyrgyz Republic

\begin{tabular}{|c|l|c|}
\hline$\#$ & \multicolumn{1}{|c|}{ Key actors } & The number of content references \\
\hline 1 & The government & 11 \\
\hline 2 & The private sector, e.g. SME & 7 \\
\hline 3 & Industries & 6 \\
\hline 4 & International organizations & 5 \\
\hline 5 & The public & 2 \\
\hline 6 & Investors & \\
\hline
\end{tabular}

Source: The author's own analysis

Next, to answer the 'resilient against what? question, the Kyrgyz government discourse points to the following major groups of critical events: gold mining (8 references), primarily with regard to the Kumtor field; followed by economic factors (total -5 references), e.g. negative trade balance and a decline in GDP; and regional factors (2 references), e.g. cooperation with other Central Asian nations and in the context of the Customs Union.

Table 5 Critical events as suggested by content analysis, the case of Kyrgyz Republic

\begin{tabular}{|l|l|c|}
\hline \multicolumn{1}{|c|}{ Groups } & \multicolumn{1}{|c|}{ Critical events } & The number of content references \\
\hline Gold mining & $\begin{array}{l}\text { Economic dependency on gold } \\
\text { (total }-8 \text { references) }\end{array}$ & 8 \\
\hline \multirow{2}{*}{ Economic factors } & Negative trade balance & 2 \\
\cline { 2 - 3 } & Declining GDP & 2 \\
\hline
\end{tabular}

BRJPD | Vol. 1 | n. 1 | p.3-24, 2019 


\begin{tabular}{|l|l|c|}
\hline (total -5 references) & Migrant remissions & 1 \\
\hline \multirow{2}{*}{ Regional factors } & $\begin{array}{l}\text { Cooperation in the Central Asian } \\
\text { region }\end{array}$ & 1 \\
\cline { 2 - 3 } (total -2 references) & The Customs Union & 1 \\
\hline
\end{tabular}

Source: The author's own analysis

As the analysis of critical events suggests, it is gold mining issues that the Kyrgyz government discourse emphasizes most, while economic and regional factors appear less pronounced. Among gold mining issues, the most prominent is Kumtor gold mining field. Located in the Issyk-Kul region, the Kumtor field operations underwent a dramatic fall in production in 2012, which led to a decline in the share of the industrial sector in GDP from 20\% in 2009-2011 to 16.8\% in 2012 (Government of Kyrgyz Republic, 2013a). Furthermore, the Kumtor factor, along with a drop in agricultural production due to unfavorable climate conditions, caused $0.9 \%$ real decline in 2012 GDP compared to $6 \%$ increase in 2011 (Government of Kyrgyz Republic, 2013b). On the contrary, the case of Kazakh government discourse suggests that critical events appear to be more evenly distributed, i.e. infrastructure projects (total 6 references), closely followed by global (5 references) and regional factors (4 references), as in Table 3. Overreaction of Kyrgyz government discourse to a single issue, i.e. the Kumtor gold mining field, may be indicative of not only economic overdependence on the mining industry but the government's vulnerability against external shocks as driven by critical events, as contrasted with the case of the Kazakh government that appears more resilient.

\section{DISCUSSION AND FINDINGS}

First, as suggested by quantitative analysis, the Kazakh government trends over the period from 2008 to 2017 generally conform to the "somewhat rigid" resilience degree of definitional rigidity, since both pre-shock and after-shock periods are characterized as stable equilibrium. On the contrary, the Kyrgyz case shows only a vague resemblance of patterns characteristic of (otherwise) strong government resilience. Thus, the Kyrgyz government appears less resilient vis-à-vis its Kazakh counterpart.

Second, content analysis focuses on key actors and critical events across the two nations. With regard to actors ( $R Q 3)$, the Kazakh government mainly refers to its own 
government agencies (38 references versus 19 references to the next key actor, the industrial sector) as part of its discourse on economic diversification, in contrast to the Kyrgyz government which exhibits lower resilience as measured by the number of references to key actors (11 references versus 7 references to the next key actor, i.e. the private sector. This suggests the presence of (relatively) more robust resilience as related to the Kazakh government, which is earlier supported by quantitative analysis observations. Next, regarding critical events (RQ 2), these are categorized into groups to facilitate better comparison across the two nations as opposed to comparing individual events. While the Kazakh case demonstrates somewhat an even distribution of attention across the event groups (i.e. infrastructure projects, global factors, and regional factors, as in Table 3), the Kyrgyz government discourse appears to overreact to a single issue, i.e. the Kumtor gold mining field (Table 5) that experienced a dramatic fall in production volumes in 2012 and, along with slowdown in agricultural production, led to $0.9 \%$ real decline of 2012 national GDP vis-à-vis 6\% GDP growth in 2011 (Government of Kyrgyz Republic, 2013b).

Greater vulnerability of the Kyrgyz government vis-à-vis its Kazakh counterpart suggests an application of the crisis exploitation theory (Boin et al. 2009), leaving less room for the direct use of government resilience framework. However, the framework remains useful in Kyrgyz context as it serves as a diagnostic tool to assess the government's capacity to pursue its agenda and to implement policies. Further, the government resilience framework is found to directly apply to the context of government discourse in Kazakhstan, not only as a diagnostic tool (RQ 1).

As a final note, this research finds that the notion of an actor's resilience may include both negative and positive connotations. On the one hand, the government should exhibit resilience to effectively lead political developments and to implement policy change. On the other hand, the government should constantly engage the wider public in its discourse to avoid democratic deficit. Defining resilience as the capacity to learn (as in McEvoy et al. 2013), policy experts across Kazakhstan and Kyrgyzstan should pursue resilience discourse through the lens of public interest (relatively higher in Kyrgyzstan) and engaging a wider range of actors (e.g. academia and quasi-state institutions as in the case of Kazakhstan).

\section{CONCLUSION AND FURTHER RESEARCH}

BRJPD | Vol. 1 | n. 1 | p.3-24, 2019 
This study appears to demonstrate the overall validity and value of the government resilience framework as applied to actor-centric agenda-setting processes and interactions, at least with regard to the economic diversification policy discourse across two Central Asian states - Kazakhstan and Kyrgyzstan. The framework's currency extends beyond its ability to assess a relative degree of government resilience in a comparative case setting. It also serves as a diagnostic tool that helps identify the government's overall capacity to effectively withstand external pressure coming from other key actors in an agenda-setting environment often characterized as politically contestable (Schattschneider 1960), while actors both from inside and outside the government wait to exploit a crisis in attempts to set their own agenda on the government (Boin et al. 2009).

Further studies should try to replicate other applications of the government resilience framework across various jurisdictions and policy areas. One possible approach is to observe its usefulness in other Eurasian nations using a comparative case method. Another possibility is to test the applicability of the framework with regard to other policy issues, e.g. corruption not only in the Eurasian context but across a wider range of developing nations. Furthermore, as mentioned earlier, the Kyrgyz government discourse appears to better respond to public needs (as measured by the number of references) while demonstrating somewhat weaker government resilience as contrasted with the Kazakh government. Yet, the Kazakh government appears to suffer from a greater degree of democratic deficit (as the public receives negligible attention in terms of content references). Thus, further research might test a possible correlation between a degree of democratic deficit and government resilience in a specific country context.

\section{References:}

Aoki, N. (2016). Adaptive governance for resilience in the wake of the 2011 Great East Japan Earthquake and Tsunami. Habitat International, 52, 20-25.

Aoki, N. (2015). Wide-area collaboration in the aftermath of the March 11 disasters in Japan: Implications for responsible disaster management. International Review of Administrative Sciences, 81(1), 196-213.

Bhamra, R., Dani, S., \& Burnard, K. (2011). Resilience: The concept, a literature review and future directions. International Journal of Production Research, 49(18), 5375-5393. doi: $10.1080 / 00207543.2011 .563826$

Birkland, T. A. (1998). Focusing events, mobilization, and agenda setting. Journal of public policy, 18(1), 53-74. 
Boin, A., 't Hart, P., \& McConnell, A. (2009). Crisis exploitation: political and policy impacts of framing contests. Journal of European Public Policy, 16(1), 81-106.

Bourbeau, P. (2015). Resilience and international politics: Premises, debates, agenda. International Studies Review, 17(3), 374-395. doi:10.1111/misr.12226

Capano, G., \& Woo, J. J. (2017). Resilience and robustness in policy design: A critical appraisal. Policy Sciences, 50(3), 399-426.

Cobb, R. \& Elder, C. (1972). Participation in American Politics: The dynamics of agenda-building. Baltimore, MD: Johns Hopkins University Press.

Dearing, J. W., \& Rogers, E. M. (1996). Agenda-setting. Thousand Oaks, Calif: Sage.

Dyussenov, M. (2017, August 17-19). Who Sets the Agenda? Analyzing key actors and dynamics of economic diversification in Kazakhstan throughout 2011-2016. Paper presented at the International Conference on Good Governance and Economic Diversification in Resource Rich Economies (GSPPCONF2017), Nazarbayev University Graduate School of Public Policy, Astana.

Government of Kyrgyz Republic (2013a, Oct 23), Directive \#426-p. Retrieved Sep 4, 2018, from: http://cbd.minjust.gov.kg/act/view/ru-ru/210037?ckwds

Government of Kyrgyz Republic (2013b, Jan 31), Decree \#42/52/1. Retrieved Sep 4, 2018, from: http://cbd.minjust.gov.kg/act/view/ru-ru/94138?ckwds

Hamel, G., \& Valikangas, L. (2004). The quest for resilience. Revista Icade. Revista de las Facultades de Derecho y Ciencias Económicas y Empresariales, (62), 355-358.

Heclo, H. (1974). Modern social politics in Britain and Sweden: From relief to income maintenance. New Haven: Yale University Press.

Howlett, M., Ramesh M, \& Perl, A. (2009). Studying Public Policy: Policy cycles \& policy subsystems (3rd ed.). Don Mills, Ont; Oxford: Oxford University Press.

Kingdon, J. W. (1984). Agendas, Alternatives and Public Policies. Boston: Little, Brown.

Leal Filho, W., Musa, H., Cavan, G., O'Hare, P., Seixas, J., \& SpringerLink (2016). Climate change adaptation, resilience and hazards (1st 2017 ed.). Cham: Springer International Publishing. doi:10.1007/978-3-319-39880-8

Lowndes, V., \& McCaughie, K. (2013). Weathering the perfect storm? Austerity and institutional resilience in local government. Policy \& Politics, 41(4), 533-549. doi:10.1332/030557312X655747

McEvoy, D., Fünfgeld, H., \& Bosomworth, K. (2013). Resilience and climate change adaptation: The importance of framing. Planning Practice and Research, 28(3), 280-293. doi:10.1080/02697459.2013.787710 
McNulty, T., \& Ferlie, E. (2004). Process transformation: Limitations to radical organizational change within public service organizations. Organization studies, 25(8), 1389-1412.

Nair, S., \& Howlett, M. (2016). From robustness to resilience: avoiding policy traps in the long term. Sustainability science, 11(6), 909-917.

Neuman, R. W., Guggenheim, L., Mo Jang, S., \& Bae, S. Y. (2014). The Dynamics of Public Attention: Agenda-setting theory meets big data. Journal of Communication, 64(2), 193-214. doi:10.1111/jcom.12088

Office of the Government of the Kyrgyz Republic (2014, May 15), Правительство КР к кониу этой недели подготовит пошагово расписанный План действий по реализации приоритетных проектов [The Government of the Kyrgyz Republic will prepare a step-by-step Action Plan for the implementation of priority projects by the end of this week]. Retrieved Sep 4, 2018, from: http://www.gov.kg/?p=10616\&lang=ru

Richardson, B. J., Le Bouthillier, Y., McLeod-Kilmurray, H., \& Wood, S. (2009). Climate Law and Developing Countries: Legal and Policy Challenges for the World Economy. Edward Elgar.

Sabatier, P. A. (1988). An advocacy coalition framework of policy change and the role of policy-oriented learning therein. Policy sciences, 21(2-3), 129-168.

Schattschneider, E. (1960). The Semi-sovereign People. NY: Holt, Rinehart and Winston

Steinberg, P. F. (2003). Understanding policy change in developing countries: The spheres of influence framework. Global Environmental Politics, 3(1), 11-32.

doi:10.1162/152638003763336365

Surminski, S., \& Leck, H. (2017). From agenda-setting to implementation: The role of multisectoral partnerships in addressing urban climate risks. Earth's Future, 5(10), 966 978.

The Ministry of Justice of the Republic of Kazakhstan (2018). Информационно-правовая Система Нормативных Правовых Актов «Әділет» [The Adilet Information and Legal System of Normative Legal Acts]. Retrieved on August 30, 2018, from: http://adilet.zan.kz/

The Ministry of Justice of Kyrgyz Republic (2018). Централизованный Банк Данных Правовой Информации Кыргызской Республики [The Centralized Database of Legal Information of Kyrgyz Republic]. Retrieved on August 30, 2018, from: http://cbd.minjust.gov.kg/ru-ru/npakr/search

The National Council for Sustainable Development of the Kyrgyz Republic (2013, Sep 27). Национальная стратегия устойчивого развития Кыргызской Республики на период 2013-2017 годы [National Sustainable Development Strategy of the Kyrgyz Republic for 2013-2017]. Retrieved Sep 4, 2018, from: http://cbd.minjust.gov.kg/act/view/ru-ru/61542 
Vickers, M. H., \& Kouzmin, A. (2001). 'Resilience' in organizational actors and rearticulating 'voice': towards a humanistic critique of New Public Management. Public Management Review, 3(1), 95-119. 